\title{
IRISOBRILLIA LONGICOSTA OLIVER, 1985 (DIPTERA: CHIRONOMIDAE: ORTHOCLADIINAE) TAKEN IN SOUTH BRAZIL
}

\author{
Trond Andersen ${ }^{1} \&$ Humberto F. Mendes ${ }^{2,3}$
}

Biota Neotropica v4 (n2) - http://www.biotaneotropica.org.br/v4n2/pt/abstract?article+BN03904022004

\author{
Date Received 06/22/2004 \\ Revised 09/13/2004 \\ Accepted 10/01/2004
}
Museum of Zoology, University of Bergen, Muséplass 3, N-5007 Bergen, Norway
${ }^{1}$ E-mail: trond.andersen@zmb.uib.no
${ }^{2}$ E-mail: hfmendes@usp.br
${ }^{3}$ Corresponding author

\begin{abstract}
Irisobrillia longicosta Oliver, originally described from Venezuela, is taken in Malaise traps close to small rivers in the state of Santa Catarina in south Brazil. The specimens from Brazil are small compared to the types from Venezuela, and are thus described in some detail. Irisobrillia is the only genus of the primitive Orthocladiinae close to the genus Brillia Kieffer occurring in the Neotropical region.
\end{abstract}

Key words: Irisobrillia, Orthocladiinae, Brazil, redescription. 


\section{Introduction}

The genus Irisobrillia was erected by Oliver (1985) based on I. longicosta Oliver, 1985 from Venezuela. Oliver (1985) considered one female from St. Vincent recorded as Erycnemus sp. by Sæther (1981) as conspecific with the males from Venezuela. Sæther \& Wang (1992) described the female from St. Vincent and pointed out that it is considerably smaller than the males and that it also apparently lacks setae on squama, which is found in the males. Later $I$. longicosta has also been recorded from Costa Rica (Watson \& Heyn 1992) and Nicaragua (Spies \& Reiss 1996).

Irisobrillia is the only genus of the primitive Orthocladiinae close to the genus Brillia Kieffer occurring in the Neotropical region. Other genera belonging to this group are Austrobrillia Freeman, Eurycnemus van der Wulp, Euryhapsis Oliver, Pseudobrillia Niitsuma, Tokyobrillia Kobayashi \& Sasa, and Xylotopus Oliver. Irisobrillia has a simple gonostylus similar to Pseudobrillia and Tokyobrillia, and a key to the species of these three genera is given by Sæther \& Wang (1992).

The record of I. longicosta from the state of Santa Catarina in south Brazil extends the known range of the species considerably. The original description of the species was based on three males only. The tarsi were lost in all three specimens and also other features are not described and figured in detail. As the species appears to be quite variable, we therefore decided to figure and describe the males from Brazil in some detail.

\section{Methods and terminology}

The material was mounted on slides in Canada balsam following the procedure outlined by Sæther (1969). The general terminology follows Sæther (1980). The measurements are given as ranges followed by a mean.

The specimens are deposited in the Museum of Zoology (ZMBN), Bergen, Norway and in the Museu de Zoologia da Universidade de São Paulo (MZUSP), São Paulo, Brazil.

\section{Irisobrillia longicosta Oliver}

(Figs. 1-9)

Irisobrillia longicosta Oliver, 1985 : 1109

Eurycnemus sp. Sæther, $1981: 2$

Material examined: Brazil: Santa Catarina: São Bento do Sul, 26¹9'25.6'S 48¹8'26.5' 'W, 13-16.x.2001, 660 m a.s.1., 11 males, Malaise trap, M.V. Yamada leg. (6 males MZUSP, 5 males ZMBN). Santa Catarina: Florianópolis, Unidade de Conservação Desterro (UCAD), $27^{\circ} 31^{\prime} 50,8^{\prime \prime}$ 'S, 48 ${ }^{\circ} 30^{\prime} 44,3^{\prime \prime} \mathrm{W}$ 08.ii-05.iii.2004, 2 males, Malaise trap, L.C. Pinho \& H. F. Mendes leg. (MZUSP).

Male (n= 8-10): Total length 2.43-3.21, $2.88 \mathrm{~mm}$. Wing length 1.32-1.75, $1.56 \mathrm{~mm}$. Total length / wing length 1.711.95, 1.84. Wing length / length of profemur 2.24-2.37, 2.32. Coloration: thorax brown, legs light brown, abdomen with brownish band in oral half of tergites II-VI, band often indicated also on tergite I and VIII.

Head (Fig. 1). AR 0.87-1.47, 1.14. Ultimate flagellomere $312-588,443 \mu \mathrm{m}$ long. Temporal setae 13-21, 16; including 410, 8 inner verticals; 2-5, 3 outer verticals; and 3-8, 5 postorbitals. Clypeus with 4-10, 7 setae. Tentorium, stipes and cibarial pump as in Fig. 2. Tentorium 111-139, $123 \mu \mathrm{m}$ long; 21-29, $25 \mu \mathrm{m}$ wide. Stipes 107-133, $117 \mu \mathrm{m}$ long; 12-18, $16 \mu \mathrm{m}$ wide. Palp segment lengths (in $\mu \mathrm{m}$ ): 18-25, 22; 39-57, 51; 94-139, 118; 76-107, 93; 86-123, 107. Third palpal segment with 3-5 sensilla clavata in apical one-third, sometimes with additional 1-2 sensilla clavata medially, 13-16 $\mu \mathrm{m}$ long; fourth palpal segment with 2 sensilla clavata subapically, 11-14 $\mu \mathrm{m}$ long.

Thorax (Fig. 3). Antepronotum with 4-9, 6 dorsomedian and 0-3, 2 ventrolateral setae. Dorsocentrals 16-22, 20, starting close to antepronotum; prealars 3-8, 6; supraalar 1 . Scutellum with 5-8, 7 setae.

Wing (Fig. 4). VR 1.61-1.88, 1.73. C extension 127-195, $159 \mu \mathrm{m}$ long. Brachiolum with 2-4, 3 setae; C extension with 36-53, 43 non-marginal setae; Sc with 25-43, 32 setae; R with 27-46, 36; $\mathrm{R}_{1}$ with 14-42, 33; $\mathrm{R}_{4+5}$ with 44-74, 63; $\mathrm{RM}$ with 2-5, 3 ; M with $0-1,0 ; \mathrm{M}_{1+2}$ with about $81-109,102 ; \mathrm{M}_{3+4}$ with 3247, 42; Cu with 26-56, 45; $\mathrm{Cu}_{1}$ with 15-24, 20; PCu with 44-84, 65; and An with 16-29, 25 setae. Wing membrane with 7-24, 14 setae in cell $\mathrm{m}$ basally of RM, other cells extensively setose. Squama with 1-4, 3 setae.

Legs. Spur of front tibia 36-44, $40 \mu \mathrm{m}$ long; spurs of 

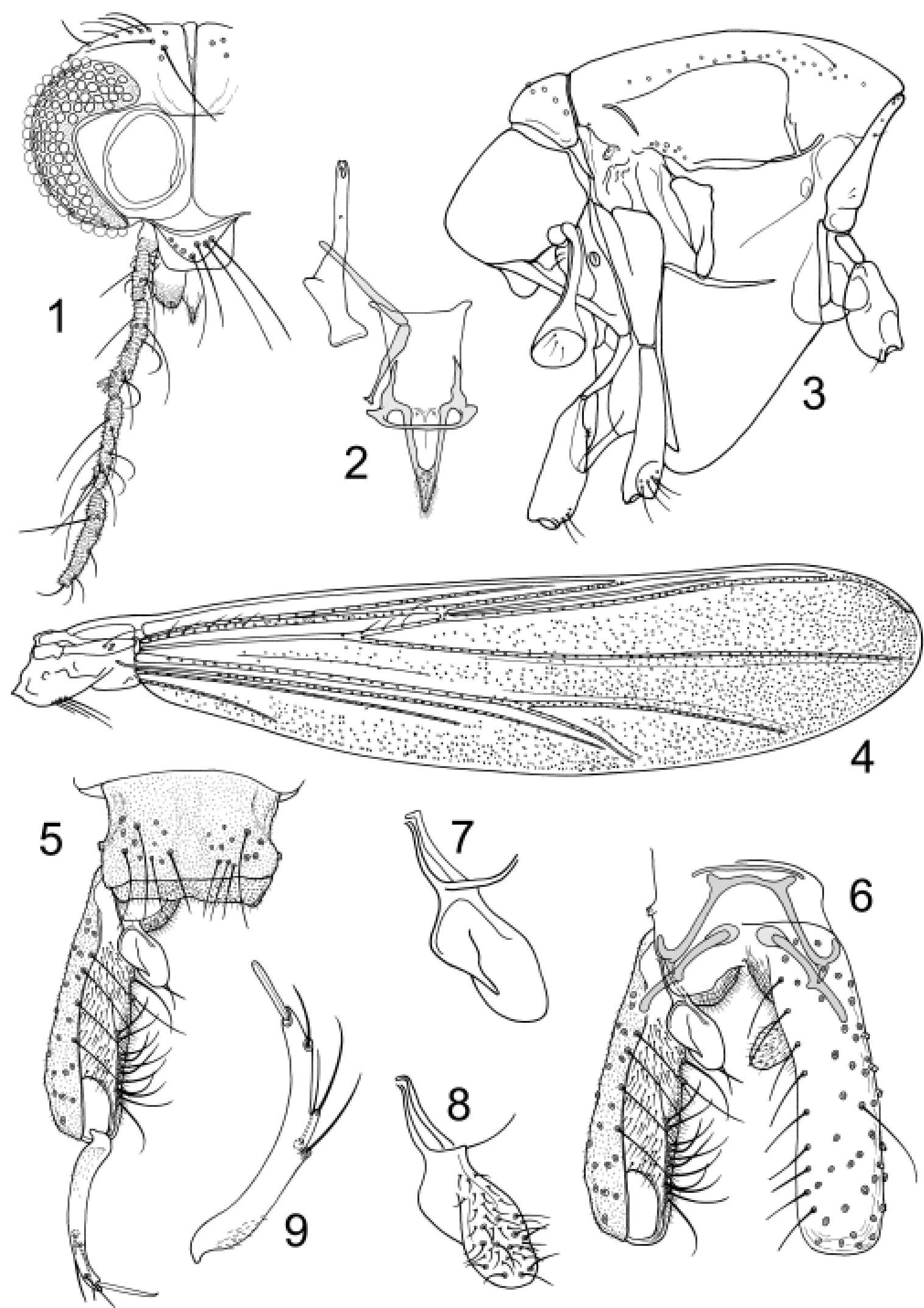

Figs 1-9. Irisobrillia longicosta Oliver, 1985, male imago from Brazil. 1, head; 2, tentorium, stipes and cibarial pump; 3, thorax; 4, wing; 5, tergite IX and dorsal aspect of left gonocoxite and gonostylus; 6, hypopygium with tergite IX and anal point removed, left dorsal aspect, right ventral aspect; 7, superior volsella, dorsal; 8, superior volsella, ventral; 9, gonostylus. 
Table 1. Lengths (in $\mu \mathrm{m}$ ) and proportion of legs of Irisobrillia longicosta Oliver $(n=5-10)$.

\begin{tabular}{|c|c|c|c|c|c|c|c|}
\hline & fe & $\mathrm{ti}$ & $\operatorname{ta}_{1}$ & \multicolumn{2}{|l|}{$\mathrm{ta}_{2}$} & $\operatorname{ta}_{3}$ & $\mathrm{ta}_{4}$ \\
\hline $\mathrm{p}_{1}$ & $621-735,691$ & $678-801,766$ & $612-719,690$ & \multicolumn{2}{|c|}{$302-384,351$} & $212-278,252$ & $139-172,160$ \\
\hline $\mathrm{p}_{2}$ & $580-768,693$ & $556-760,684$ & $335-490,413$ & \multicolumn{2}{|c|}{$155-237,203$} & $114-179,148$ & $82-106,95$ \\
\hline $\mathrm{p}_{3}$ & $613-792,723$ & $678-915,822$ & $402-596,504$ & \multicolumn{2}{|c|}{$221-327,276$} & $139-261,202$ & $90-163,118$ \\
\hline & $\mathrm{ta}_{5}$ & LR & \multicolumn{2}{|l|}{$\mathrm{BV}$} & \multicolumn{2}{|l|}{$\mathrm{SV}$} & $\mathrm{BR}$ \\
\hline $\mathrm{p}_{1}$ & $57-65,60$ & $0.88-0.91,0.90$ & \multicolumn{2}{|c|}{$2.50-2.69,2.63$} & \multicolumn{2}{|c|}{$2.12-2.17,2.14$} & $4.40-5.63,5.23$ \\
\hline $\mathrm{p}_{2}$ & $41-57,49$ & $0.60-0.65,0.61$ & \multicolumn{2}{|c|}{$3.50-3.69,3.58$} & \multicolumn{2}{|c|}{$3.08-3.39,3.29$} & $5.20-6.00,5.58$ \\
\hline $\mathrm{p}_{3}$ & $49-74,60$ & $0.59-0.65,0.62$ & \multicolumn{2}{|c|}{$2.88-3.65,3.18$} & \multicolumn{2}{|c|}{$2.86-3.27,3.03$} & $5.33-7.92,6.67$ \\
\hline
\end{tabular}


middle tibia 35-47, $41 \mu \mathrm{m}$ and 36-47, $42 \mu \mathrm{m}$ long; spurs of hind tibia 44-58, $50 \mu \mathrm{m}$ and 47-61, $53 \mu \mathrm{m}$ long. Width at apex of front tibia 33-40, $37 \mu \mathrm{m}$; of middle tibia 35-47, $41 \mu \mathrm{m}$; of hind tibia 36-47, $42 \mu \mathrm{m}$. Comb lacking. Lengths and proportions of legs as in Table 1.

Hypopygium (Figs 5-6). Tergite IX with 15-25, 20 setae in two groups; laterosternite IX with 1-3, 2 setae. Phallapodeme 74-96, $85 \mu \mathrm{m}$ long; transverse sternapodeme 47-66, $59 \mu \mathrm{m}$ long. Gonocoxite 211-246, $227 \mu \mathrm{m}$ long. Superior volsella (Figs 7-8) 55-66, $61 \mu \mathrm{m}$ long; 23-28, $25 \mu \mathrm{m}$ wide; with 12-16, 14 weak setae and strong microtrichia ventrally. Gonostylus (Fig. 9) 109-146, $128 \mu \mathrm{m}$ long; megasetae 39-46, $42 \mu \mathrm{m}$ long; with 2-3, 2 preapical seta, 49-62, $56 \mu \mathrm{m}$ and 3954, $48 \mu \mathrm{m}$ long; and 1 subapical seta, $28-41,34 \mu \mathrm{m}$ long. HR 1.69-1.93, 1.79; HV 2.05-2.45, 2.26.

\section{Remarks}

The Brazilian specimens falls well within the species description given by Oliver (1985), although they might be comparatively small. The wing of the largest specimen from Venezuela is $2.75 \mathrm{~mm}$ long, while the wing length of the largest Brazilian specimen measured is $1.75 \mathrm{~mm}$.

The specimens from São Bento do Sul were sampled during a project carried out by the Museu de Zoologia da Universidade de São Paulo on the biodiversity of Hymenoptera in the remains of the Atlantic Forest. The specimens collected in Unidade de Conservação Desterro were caught in a Malaise trap situated close to a fast flowing stream with sandy bottom. Biodiversity studies, headed by Dr. Carlos Brisola Marcondes, Universidade Federal de Santa Catarina (UFSC), have been carried out in this area.

The immatures of Irisobrillia remain unknown.

\section{Acknowledgements}

We are indebted to M. V. Yamada for providing us with the material from São Bento do Sul. The junior author received a grant from FAPESP (00/05903-9 and 02/12180-9) within the BIOTA/FAPESP - The Biodiversity Virtual Institute Program (www.biota.org.br). Thanks are also due to the Programa de Pós-Graduação em Entomologia da FFCLRPUSP (CAPES-PROAP) for financial support during fieldwork.

\section{References}

OLIVER, D.R. 1985. Review of Xylotopus Oliver and description of Irisobrillia n. gen. (Diptera: Chironomidae). Can Ent. 117:1093-1110.

SÆTHER, O.A. 1969. Some Nearctic Podonominae, Diamesinae and Orthocladiinae (Diptera : Chironomidae). Bull. Fish. Res. Bd Can. 107:1-154.

SÆTHER, O.A. 1980. Glossary of Chironomid morphology terminology (Diptera : Chironomidae). Ent. scand., Suppl. 14:1-51.

SÆTHER, O.A. 1981. Orthocladiinae (Diptera : Chironomidae) from the British West Indies, with description of Antillocladius n. gen., Lipurometriocnemus n. gen., Compterosmittia n. gen. and Diplosmittia n. gen. Ent. scand., Suppl. 16:1-46.

SÆTHER, O.A. \& WANG, X. 1992. Euryhapsis fuscipropes sp. n. from China and Tokyobrillia anderseni sp. n. from Tanzania, with a review of genera near Irisobrillia Oliver (Diptera : Chironomidae). Annls Limnol. 28:209-223.

SPIES, M. \& REISS, F. 1996. Catalog and bibliography of Neotropical and Mexican Chironomidae (Insecta, Diptera). Spixiana, Suppl. 22: 61-119.

WATSON, C.N., Jr. \& HEYN, M.W. 1992. A preliminary survey of the Chironomidae (Diptera) of Costa Rica, with emphasis on the lotic fauna. Neth. J. Aquatic Ecol. 26: 257-262.
Title: Irisobrillia longicosta Oliver, 1985 (Diptera:

Chironomidae: Orthocladiinae) taken in south Brazil

Authors: Trond Andersen \& Humberto F. Mendes

Biota Neotropica, Vol. 4 ( number 4): 2004

http://www.biotaneotropica.org.br/v4n2/pt/ abstract?article+BN03904022004

Date Received 06/22/2004 - Revised 09/13/2004

Accepted 10/01/2004

ISSN 1676-0611 